\title{
Morpho-Physiological Characterization of Diverse Rice Genotypes for Seedling Stage High- and Low-Temperature Tolerance
}

\author{
Kambham Raja Reddy ${ }^{1, *(1)}$, Akanksha Seghal ${ }^{1}$, Salah Jumaa ${ }^{1,2}{ }^{2}$, Raju Bheemanahalli ${ }^{1}\left(\right.$, Naqeebullah Kakar ${ }^{1}$, \\ Edilberto D. Redoña ${ }^{3}$, Chathurika Wijewardana ${ }^{1}$, Firas Ahmed Alsajri ${ }^{1,2}$, Daryl Chastain ${ }^{3}$, Wei Gao ${ }^{4}$, \\ Shasthree Taduri ${ }^{1}$ and Ajaz A. Lone ${ }^{1}$ \\ 1 Department of Plant and Soil Sciences, Box 9555, 117 Dorman Hall, Mississippi State University, \\ Mississippi State, MS 39762, USA; as5002@msstate.edu (A.S.); shj44@msstate.edu (S.J.); \\ rajubr@pss.msstate.edu (R.B.); naqeeb.hassas@yahoo.com (N.K.); gwijewa@clemson.edu (C.W.); \\ faa34@msstate.edu (F.A.A.); shastri.taduri@gmail.com (S.T.); ajazlone@skuastkashmir.ac.in (A.A.L.) \\ 2 Field Crops Department, Tikrit University, Tikrit 009642, Iraq \\ 3 Delta Research and Extension Center, Mississippi State University, 82 Stoneville Road, \\ Stoneville, MS 38776, USA; edredona@drec.msstate.edu (E.D.R.); drc373@msstate.edu (D.C.) \\ 4 USDA UV-B Monitoring and Research Program, Natural Resource Ecology Lab., Colorado State University, \\ Fort Collins, CO 80523, USA; wei.gao@colostate.edu \\ * Correspondence: krreddy@pss.msstate.edu; Fax: +1-662-325-9461
}

Citation: Reddy, K.R.; Seghal, A.; Jumaa, S.; Bheemanahalli, R.; Kakar, N.; Redoña, E.D.; Wijewardana, C.; Alsajri, F.A.; Chastain, D.; Gao, W.; et al. Morpho-Physiological

Characterization of Diverse Rice Genotypes for Seedling Stage Highand Low-Temperature Tolerance. Agronomy 2021, 11, 112. https:// doi.org/10.3390/agronomy11010112

Received: 21 December 2020

Accepted: 5 January 2021

Published: 8 January 2021

Publisher's Note: MDPI stays neutral with regard to jurisdictional clai$\mathrm{ms}$ in published maps and institutional affiliations.

Copyright: $(\odot 2021$ by the authors. Licensee MDPI, Basel, Switzerland. This article is an open access article distributed under the terms and conditions of the Creative Commons Attribution (CC BY) license (https:// creativecommons.org/licenses/by/ $4.0 /)$.

\begin{abstract}
Extreme temperatures are considered one of the main constraints that limit the growth and development of rice. We elucidated the root and shoot developmental plasticity of 64 rice genotypes during early seedling establishment, using the sunlit plant growth chambers at 22/14 (low), 30/22 (optimum), and $38 / 30{ }^{\circ} \mathrm{C}$ (high) day/night temperatures. Low temperature severely inhibited 23 traits, such as shoot (68\%), root (57\%), and physiological (35\%) attributes. On the contrary, the high temperature positively affected most of the shoot (48\%) and root (31\%) traits, except root diameter and root/shoot ratio, compared with the optimum. Alternatively, leaf chlorophyll fluorescenceassociated parameters declined under low (34\%) and high ( $8 \%$ ) temperatures. A weak correlation between cumulative high-temperature response index (CHTRI) and cumulative low-temperature response index (CLTRI) indicates the operation of different low- and high-temperature tolerance mechanisms at the early seedling stage. Groups of distinct rice genotypes associated with low or high-temperature tolerance were selected based on CHTRI and CLTRI. The genotypes that commonly performed well under low and high temperatures (IR65600-81-5-2-3, CT18593-1-7-2-2-5, RU1504114, RU1504122, Bowman, and INIA Tacuari) will be valuable genetic resources for breeders in developing early-season high- and low-temperature-tolerant genotypes for a broad range of both tropical and temperate rice-growing environments.
\end{abstract}

Keywords: cold and heat temperature tolerance; early growth stage; rice; roots; cumulative stress response indices

\section{Introduction}

Rice (Oryza sativa L.) is one of the major cereal crops grown under different agroecosystems. Globally, the harvested rice area had increased from 120.1 million ha in 1960 to 161.6 million ha in 2018. During this time, the average rice yield doubled from 1.84 to 4.51 tons ha ${ }^{-1}$ (http:/ / ricestat.irri.org:8080/wrsv3/entrypoint.htm). Rice is the staple food for 2.5 billion people globally, particularly in Asia; 1.7 billion people depend solely on rice for their livelihood [1,2]. Although rice is grown in different climatic regions (temperate, tropical, and subtropical), it is challenging to maintain rice productivity at a high level due to its higher sensitivity to unfavorable environmental conditions [3,4]. Crop production faces multiple challenges, with $>50 \%$ of plant productivity often decreased by various abiotic stresses [5]. Similarly, rice productivity in most rice-growing areas suffers 
from one or two extreme production challenges at the same or different periods of any growing season [6]. With the increasing demand for food production, unfavorable environmental conditions such as extreme temperatures (low and high), drought, submergence, and salinity, are becoming threats to sustaining yield [5-7].

In addition to climatic challenges, escalating labor wages and declining labor force for agriculture $(0.2 \%$ per year $)$ in the rice-growing regions are forcing farmers to change their rice cultivation practices [8]. Thus, in recent years, dry direct-seeded rice cultivation has been increasingly adopted by farmers as a feasible alternative to the traditional puddled-rice method. However, the cultivation transformation has been coupled with an underlying risk of yield loss due to extreme temperatures and soil moisture regimes during early seedling establishment [9]. More than 15 million ha of rice areas suffer from a low-temperature injury at one or more growth stages $[10,11]$. For example, rice cultivation in the northern part of Vietnam is hampered by cold temperatures at the germination and seedling stages $[12,13]$. On the other hand, high precipitation, coupled with a colder climate, affects $7 \%$ of Africa's total rice area [14]. Similar production challenges have been reported in rice-growing areas of the Mid-South in the USA. Generally, rice is adversely affected by high temperatures in the tropics and lower elevations, and lower temperatures in the temperate regions. The optimum temperature for rice seed germination and emergence is between $25^{\circ} \mathrm{C}$ and $30^{\circ} \mathrm{C}$. Temperatures below $15^{\circ} \mathrm{C}[10,15]$ or $>35^{\circ} \mathrm{C}[16]$ severely affect the growth and development of rice during the early growth stages. For instance, extreme temperatures can affect rice growth and development processes, including germination, emergence and seedling establishment, and reproductive and grain-filling stages. The low (cold) temperature in the vegetative stage can cause slow growth; reduced seedling vigor [12,17], number of seedlings, and tillering [18]; and increased plant mortality $[11,19]$. Cold tolerance at the early stages is essential to obtain the optimum plant population [20] required for successful crop production. Adding to the challenge, temperatures $>32{ }^{\circ} \mathrm{C}$ negatively affect all growth and development $[6,16,21]$. Hence, there is a strong need to investigate seedling growth and development influenced by extreme temperature conditions [22].

Death at the seedling stage and uneven seedling establishment cause yield loss under low- and high-temperature stress. Increased productivity under unfavorable environmental conditions can be achieved by improving seedling survival and vigor at the early growth stage. Compared with other crops, rice seems to be more sensitive to extreme (low and high) temperature stress [20,22]. Rice is a cold-sensitive crop; crop growth and development are severely damaged below $15{ }^{\circ} \mathrm{C}$ [22]. Temperature $<15^{\circ} \mathrm{C}$ causes poor germination, late seedling establishment, and non-vigorous plants, which results in loss of seedling and delay in the transplanting period. Breeding genotypes with temperature tolerance could be the best solution for minimizing the influence of low temperature in high-altitude rice-growing areas and temperate zones, or high temperature in tropical, low-altitude rice-growing regions during the early seedling stage in direct-seeding cultivation. Earlyseason vigor is an essential trait in rice development, playing a crucial role in canopy development and light interception. During seedling establishment under a dynamic environment, low root vigor can potentially affect canopy development at the plant's later stage $[16,23,24]$. Selection for tolerance based on root traits is often challenging under field conditions and involves tedious work $[16,25,26]$. Previous rice studies extensively focused on reproductive-stage temperature tolerance due to its high sensitivity and its immediate relevance to grain yield $[22,27]$. Hence, knowledge on how early-season shoot and root vigor of rice are affected by extreme temperatures is essential for identifying rice genotypes with high levels of low-/high-temperature tolerance to minimize the production risk under direct-seeded cultivation. It is still unclear how different rice subspecies and breeding lines would respond to low and high temperatures at the seedling stage.

Therefore, understanding the temperature tolerance of diverse rice genotypes involving different subspecies (indica and japonica) and advanced breeding lines would be necessary for formulating any temperature stress mitigation strategy through varietal 
improvement. Moreover, few studies that have assessed genetic diversity for temperature tolerance in rice have used selection parameters such as spikelet fertility that can be observed only at later growth stages [22]. Therefore, to address the above knowledge gaps, we utilized a diverse rice panel involving pure lines from both the indica and japonica major rice subspecies, comprised of both released varieties and breeding lines to evaluate physiological, growth, and development traits using a precise phenotyping approach at the early growth stage. The objectives of this study were to (i) determine variations in low and high temperature tolerance among 64 rice genotypes, (ii) determine which traits among the genotypes are best suited for screening cold and heat stress tolerance, and (iii) classify and rank rice genotypes based on a stress response for cold and heat tolerance. We expect that the identified tolerant genotypes will help breeders develop rice strains or varieties with tolerance to cold and/or heat stress. On the other hand, crop consultants can use stress-response scores as a decision-making tool to select genotypes best suited for rice production in regions where extreme temperatures limit rice growth.

\section{Materials and Methods}

\subsection{Crop Husbandry}

We used a rice panel consisting of a diverse set of 64 rice genotypes ( 31 indica, 32 japonica, and one Aus subspecies, comprised of 27 released varieties and 37 experimental breeding lines under development) that were used in this study (Table S1). The collected genotypes were phenotyped for the low and high temperatures stress-tolerance variability at the early seedling stage using the sunlit soil-plant-atmosphere research (SPAR) [28] chambers at the Mississippi State University, Mississippi State, MS. Each SPAR chamber consists of a steel soil bin $(1-\mathrm{m}$ deep $\times 2-\mathrm{m}$ long $\times 0.5-\mathrm{m}$ wide $)$ and a $1.27-\mathrm{cm}$ thick Plexiglas chamber $(2.5-\mathrm{m}$ tall $\times 2.0$-m long $\times 1.5-\mathrm{m}$ wide) to accommodate root and aerial plant parts, respectively. The Plexiglas allows $97 \%$ of the visible solar radiation to pass without spectral variability in absorption (wavelength 400-700 $\mathrm{nm}$ ) [29].

Seeds were sown on 17 October 2016 in 576 polyvinyl-chloride pots (10.1-cm diameter and 45.72-cm height) filled with the soil medium consisting of 3:1 sand/topsoil ratio classified as a sandy loam (87\% sand, $2 \%$ clay, and $11 \%$ silt) with a $500 \mathrm{~g}$ of gravel at the bottom of each pot. The pots were arranged with 64 in each of the 9 SPAR units. Initially, four seeds were sown in each pot, and $11 \mathrm{~d}$ after emergence the seedlings of similar size were replanted to one per pot. Pots were arranged as a randomized complete block in 16 rows, with four pots per row in each SPAR chamber. Plants were irrigated three times a day through an automated, computer-controlled drip system with full-strength Hoagland's nutrient solution [30], delivered at 0700, 1200, and $1700 \mathrm{~h}$, in each SPAR unit. Each SPAR unit's microclimatic environment was continuously monitored using a dedicated computer system [28]. Each chamber's relative humidity was monitored with a humidity and temperature sensor (HMV 70Y, Vaisala, Inc., St. Louis, MO, USA) installed in airline ducts' returning path.

\subsection{Temperature Treatments}

In this study, 576 plants (64 rice genotypes $\times$ three treatments $\times$ three replications) were used to explore phenotypic variability among genotypes. The seedlings were grown under the optimum temperature of $30 / 22{ }^{\circ} \mathrm{C}$ (day/night) temperatures with $70 \%$ relative humidity and $410 \mathrm{PPM} \mathrm{CO}_{2}$ for ten days to facilitate uniform emergence. Three temperature treatments $\left(22 / 14,30 / 22\right.$, and $38 / 30{ }^{\circ} \mathrm{C}$, day /night) were randomly arranged in nine SPAR units. All genotypes were moved into three treatments $10 \mathrm{~d}$ after planting: control or optimum-temperature $\left(30 / 22{ }^{\circ} \mathrm{C}\right.$ day/night), low-temperature $\left(22 / 14{ }^{\circ} \mathrm{C}\right.$ day/night $)$, and high-temperature $\left(38 / 30^{\circ} \mathrm{C}\right.$, day/night) treatments. The daytime temperatures were initiated at sunrise and returned to the nighttime temperature $1 \mathrm{~h}$ after sunset. Except for the temperature treatments, the other growth conditions were the same during the experiment for all the units. For each treatment, three replications were maintained by using one SPAR unit as one replication. 


\subsection{Data Collection}

\subsubsection{Physiology}

The chlorophyll index was measured using a SPAD-502 chlorophyll meter (Konica Minolta Inc., Mississauga, ON, Canada) at 30 days after sowing (DAS). Chlorophyll fluorescence $\left(\mathrm{F}_{\mathrm{v}} / \mathrm{F}_{\mathrm{m}}\right)$ was measured using the Fluropen 1000 (Photo System Instruments, Kolackova, Czech Republic) for OJIP analysis. Application of chlorophyll fluorescence fast-transient analysis (OJIP) is a simple and non-invasive tool for monitoring chloroplast function. The OJIP analysis is a sensitive, reliable, and quick test for the photosynthetic system's functionality and vitality. Minimal fluorescence intensity $\left(F_{0}\right)$, maximal fluorescence intensity $\left(\mathrm{F}_{\mathrm{m}}\right)$, maximal variable fluorescence $\left(\mathrm{F}_{\mathrm{v}}\right)$, and $\mathrm{F}_{\mathrm{v}} / \mathrm{F}_{\mathrm{m}}$ were used to get the maximum potential quantum efficiency of Photosystem II to derive clues about the stress effect on the experimental rice genotypes.

\subsubsection{Phenotyping of Agronomic Traits}

Tiller number (TN) and the total number of leaves (LN) were counted, and plant height $(\mathrm{PH})$ was measured on all plants at 30 DAS. Leaf area (LA) was measured using the LI3100 leaf-area meter (LI-COR, Inc., Lincoln, NE, USA) Total dry weights (stem + leaf + root) were measured at $31 \mathrm{DAS}$ (after the harvest) from all plants after oven drying at $75^{\circ} \mathrm{C}$ until a constant weight was reached.

\subsubsection{Root Phenotypes}

Roots were cut and separated from the stems and washed thoroughly, avoiding any disturbance to the root system. The longest root length was determined using a ruler. The cleaned individual root systems were floated in $5 \mathrm{~mm}$ of water in a $0.3-$ by $0.2-\mathrm{m}$ Plexiglas tray. Roots were untangled and separated with a plastic paintbrush to minimize root overlap. The roots were scanned with an Epson Expression 11000XL scanner at a resolution of 800 dots per inch. Acquired images were analyzed for the cumulative root length (RL), root surface area (RSA), average root diameter (RD), root volume (RV), number of roots (RN), number of root tips (RT), number of root forks (RF), number of root crossings (RC), and root:shoot ratio (RS) and images were analyzed using WinRHIZO Pro 2009C software (Regent Instruments, Inc., Québec, QC, Canada).

\subsection{Statistical Analysis}

The 64 rice genotypes were classified into cold-tolerant and heat-tolerant groups based on the summation of all genotypes' response indices, following the approach used in other crops. Initially, an individual low-temperature stress response index (ILSRI) $\left(22 / 14^{\circ} \mathrm{C}\right)$ for each of the parameters was calculated as the value of a parameter $(P \mathrm{l})$ at the low temperature of a given genotype divided by the value for the same parameter $(\mathrm{Po})$ at the optimum temperature $\left(30 / 22^{\circ} \mathrm{C}\right)$ (Equation (1)). The individual high-temperature stress response index (IHSRI) $\left(38 / 30^{\circ} \mathrm{C}\right)$ was determined by dividing the value of a parameter $(\mathrm{Ph})$ at a high temperature of a given genotype by the value for the same parameter $(\mathrm{Po})$ at the optimum temperature (Equation (2)).

$$
\begin{aligned}
\text { ILSRI (low) } & =\mathrm{Pl} / \mathrm{Po}_{\mathrm{o}} \\
\text { IHSRI (low) } & =\mathrm{Ph} / \mathrm{Po}^{\circ}
\end{aligned}
$$

Then, the combined low-temperature response index (CLTRI) and combined hightemperature response index (CHTRI) for each genotype (Equations (3) and (4)) were calculated as the sum of 24 ISRIs derived from tiller number (TN), number of leaves (LN), plant height (PH), leaf area (LA), leaf weight (LWT), root dry weight (RWT), aboveground dry weight (SHWT), stem weight (StWT), total seedling dry weight (TdWT), root length (RL), root surface area (RSA), average root diameter (AvgRD), root volume (RV), root number $(\mathrm{RN})$, root tips (RT), root forks $(\mathrm{RF})$, root crossing $(\mathrm{RC})$, root:shoot ratio 
$(\mathrm{R} / \mathrm{S})$, chlorophyll index (SPAD), minimal fluorescence intensity $\left(\mathrm{F}_{\mathrm{o}}\right)$, maximal fluorescence intensity $\left(\mathrm{F}_{\mathrm{m}}\right)$, maximal variable fluorescence $\left(\mathrm{F}_{\mathrm{v}}\right)$, and $\mathrm{F}_{\mathrm{v}} / \mathrm{F}_{\mathrm{m}}$.

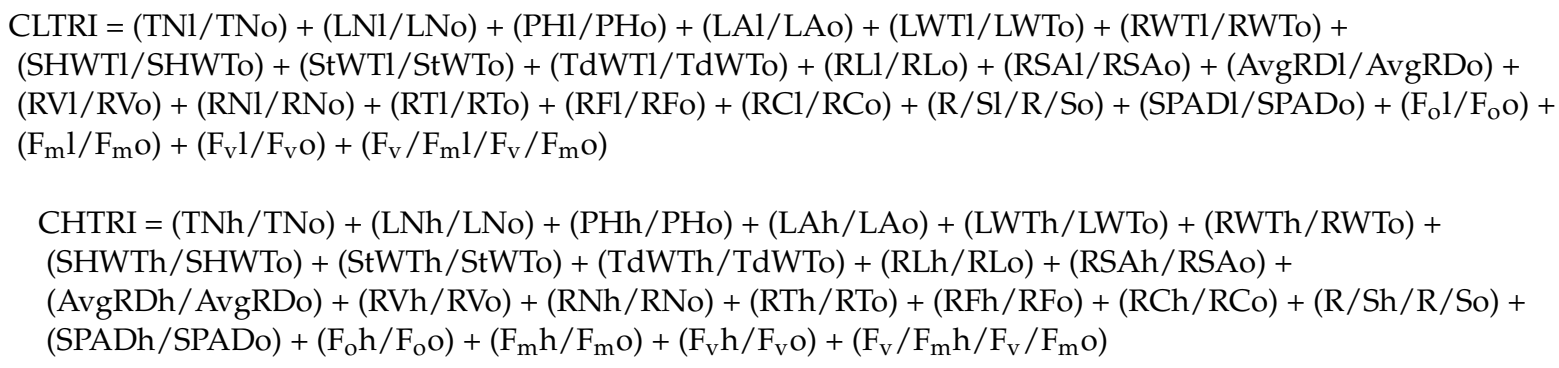

Statistical analyses were carried out using RStudio 3.6.1 (https://rstudio.com/). An ANOVA was performed for each of the traits to estimate the significance of genetic variability among rice genotypes under treatments using the library ("agricolae"). Principal component analysis, a multidimensional preference analysis technique that identifies the parameters that best describe tolerance to response variables, was used to separate genotypes into tolerant and sensitive groups. These relative index values were used to perform principal component analysis (PCA) using XLSTAT. A correlation matrix was developed using the library ("corrplot").

Furthermore, $\mathrm{Z}$ scores of the combined low-temperature response index (CLTRI) and combined high-temperature response index (CHTRI) were estimated for each of the genotypes. The computed $\mathrm{Z}$ scores were used to group rice genotypes into possible high-temperature-tolerant and low-temperature-tolerant (HTT + LTT), high-temperaturetolerant and low-temperature-sensitive (HTT + LTS), high-temperature-sensitive and lowtemperature-tolerant (HTS + LTT), and high-temperature-sensitive and low-temperaturesensitive (HTS + LTS) groups. Sigma Plot 13 was used for plotting graphs and regression analysis.

\section{Results and Discussion}

Attaining high yield under suboptimal growing conditions is one of the main challenges of this century. It is now clear that the emphasis on stress tolerance in plants has to be addressed from the vegetative to grain-filling stages because of their greater sensitivity to environmental variations $[12,16,23]$. Current constraints caused by extreme temperatures related to yield losses at the reproductive stage have gained much attention among researchers. However, investigating the multifaceted concerns connecting with growth and development continues to be a primary task. Here, we elucidate the root and shoot developmental plasticity of 64 rice genotypes to low or high temperatures at the early rice seedling stage.

\subsection{Shoot Growth and Development}

The low temperature had a significant inhibitory effect on all the rice shoot growth and developmental traits, except for leaf number under low temperature compared with the optimum temperature (Figure 1). For example, there was a $73 \%$ decrease in plant height due to cold stress compared with its control counterparts (Figure 1A; Table S1). Tiller number, a critical component of grain yield, also decreased by $61.5 \%$ under low-temperature conditions (Figure 1B). The direct effect of temperature on the shoot meristem, or its effect on reduced nutrient uptake through the roots, will affect shoot development at suboptimal soil temperatures [31]. Leaf growth is sensitive to various environmental stresses such as low temperature [18,32], water deficits [33], and nitrogen deficiency [34]. Generally, cold temperature slows the leaf initiation rate, reducing the leaf number, and directly lowering the leaf cell division and elongation [35,36], resulting in lower leaf and leaf dry weight. However, there was no effect of cold temperatures on leaf number in the present study (Figure 1C). Still, there was a considerable decline in leaf area (nearly $90 \%$ ) under the low temperature (Figure 1D). The highest value for leaf area at $22 / 14{ }^{\circ} \mathrm{C}$ was recorded 
in FEDEARROZ MOCARE (an indica released genotype, $15.68 \mathrm{~cm}^{2} /$ plant). In contrast, at $30 / 22{ }^{\circ} \mathrm{C}$, the highest value was recorded in CT18372-8-1-6-3-1-5 (an indica experimental breeding line, $363.55 \mathrm{~cm}^{2} /$ plant). Thus, leaf area could be used as a primary selection criterion for the improvement of low-temperature adaptation. As plant growth and development play essential roles in crop production, any factor governing the production of new leaves, leaf expansion duration, and stem extension will affect canopy development and radiation interception and, thus, crop yield [37,38]. Based on the observed results, we conclude that leaf traits (leaf area, leaf weight, and total biomass) have more significant potential to discriminate rice genotypes under low-temperature stress.

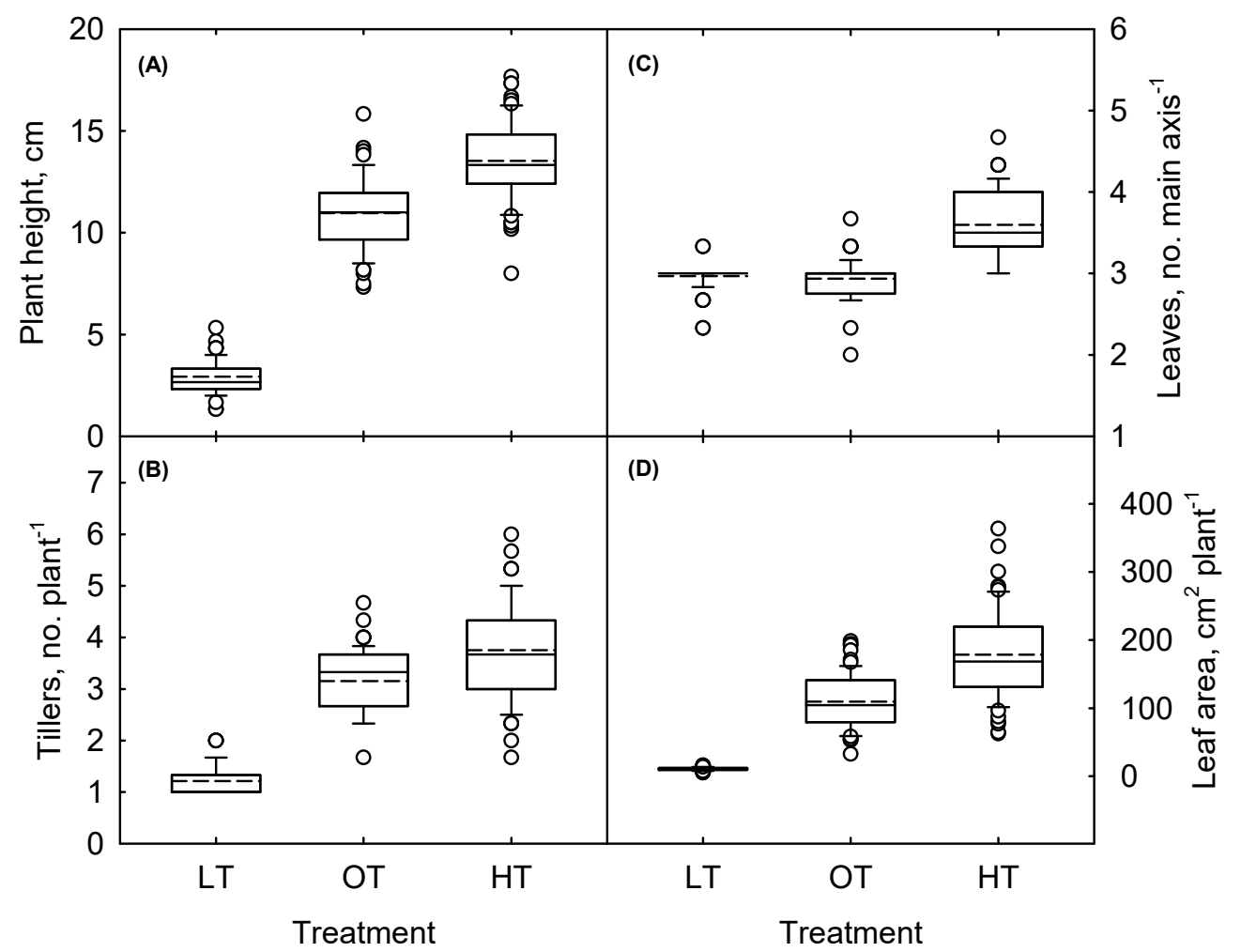

Figure 1. Temperature effect on (A) plant height, (B) tillers number, (C) leaves number, and (D) leaf area of 64 rice genotypes. Measurements were taken at 21 days after sowing. The middle line indicates the median; the box shows the range of the 25th to 75 th percentiles of the total data. The whiskers indicate the interquartile range, and the outer dots are outliers: low temperature (LT), optimum temperature (OT), and high temperature (HT).

Unlike the response of shoot and leaf phenotype to low temperature, high temperature positively affected plant height, tiller number, leaf area, and leaf number (Figure 1). However, rice genotypes displayed genetic diversity in response to high temperatures. Plants were generally taller at $38 / 30^{\circ} \mathrm{C}$ with maximum height recorded in N-22 $(17.67 \mathrm{~cm} /$ plant $)$ in comparison to plants growing at $30 / 22{ }^{\circ} \mathrm{C}$ with the maximum plant heightbeing $15.83 \mathrm{~cm} /$ plant (IR86052-32-3-2, an indica breeding line). Total leaf number per seedling increased with an increase in temperature across genotypes; however, although very small, differences were recorded among the genotypes. Leaf number ranged between $3 /$ plant to 4.67 /plant with an overall average of 3.60 /plant at $38 / 30{ }^{\circ} \mathrm{C}$ (Figure 1; Table S1). On average, leaf area increased by $62 \%$ under high-temperature conditions compared with optimum conditions among all the genotypes (Figure 1D).

\subsection{Dry Weight Traits}

Dry matter increased significantly across genotypes at high temperature but declined as temperature treatments decreased relative to optimum temperature conditions (Figure 2; 
Table S2). Among the 64 genotypes, significant variation was observed for leaf dry weight (LDW), with a high value of $0.06 \mathrm{~g}$ for FEDEARROZ 473 (an indica genotype) and CL271 (a released japonica genotype), and a low value of $0.02 \mathrm{~g}$ for SABINE (a japonica released genotype), respectively, with an overall mean of $0.04 \mathrm{~g}$ at low temperature (Figure 2C; Table S2). Leaf dry weight increased almost $77 \%$ in the genotypes growing at $38 / 30{ }^{\circ} \mathrm{C}$ with the maximum value recorded in RU1204197 (a japonica breeding line, $1.13 \mathrm{~g} / \mathrm{plant}$ ). Similarly, the least values for shoot dry weight (Figure 2B), root dry weight (Figure 2C), and total dry weight were observed at $22 / 14^{\circ} \mathrm{C}$ (Figure 2D).

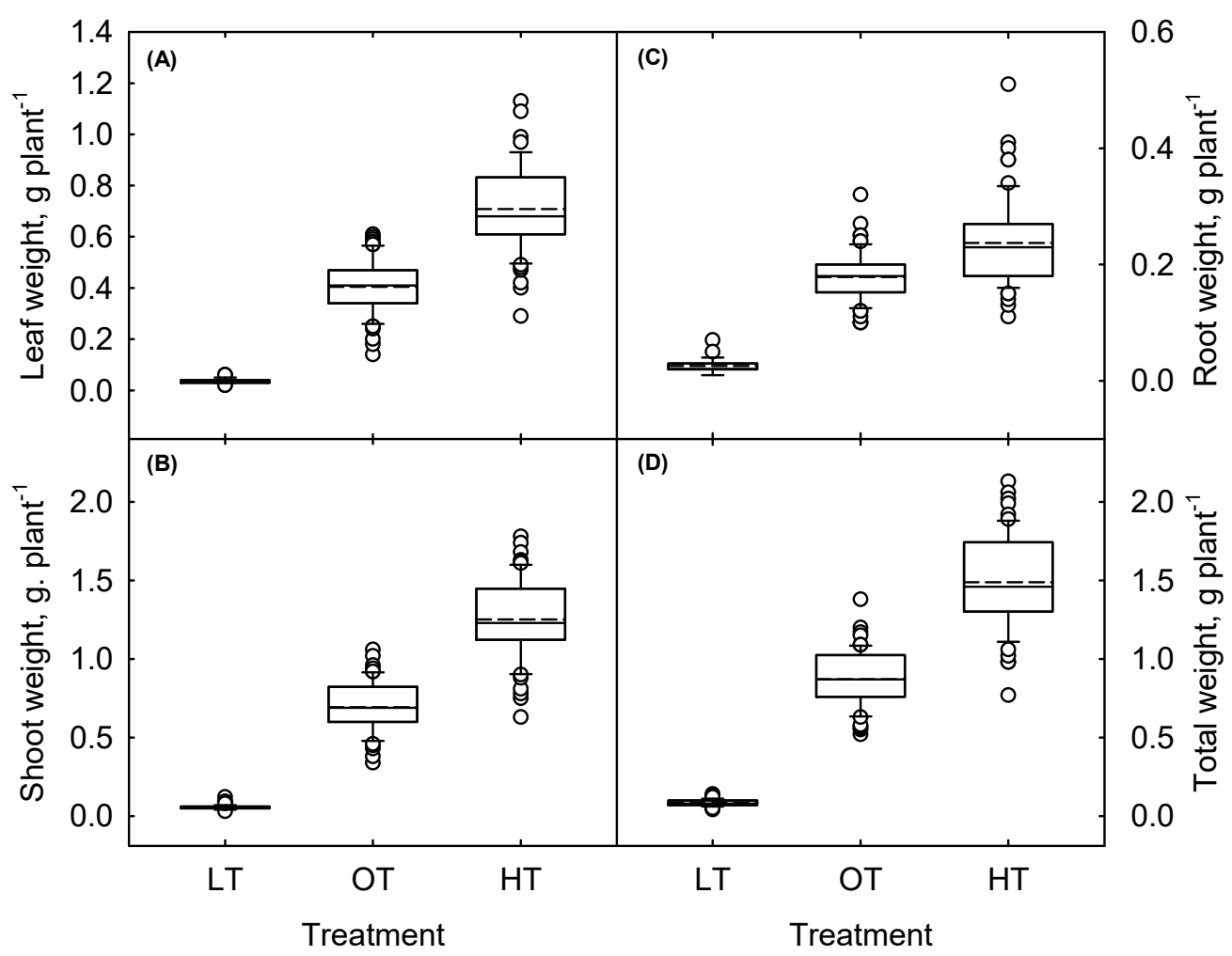

Figure 2. Low temperature (LT), optimum temperature (OT), and high temperature (HT) effects on (A) leaf weight, (B) shoot weight, (C) root weight, and (D) total weight of 64 rice genotypes. Measurements were taken at 31 days after sowing. The middle line indicates the median; the box shows the range of the 25 th to 75 th percentiles of the total data. The whiskers indicate the interquartile range, and the outer dots are outliers.

There was no significant difference among the genotypes in shoot dry weight at $22 / 14^{\circ} \mathrm{C}$. An indica breeding line, 12DS-GMET-25, showed maximum values for shoot dry weight of $0.9 \mathrm{~g} /$ plant and $1.78 \mathrm{~g} /$ plant at $30 / 22^{\circ} \mathrm{C}$ and $38 / 30^{\circ} \mathrm{C}$, respectively. In contrast, IRRI 123 (an indica released genotype that is widely grown in Asia) showed the least values for shoot dry weight at optimum and high-temperature conditions. At low and optimum temperatures, root dry weight values ranged from 0.01 (IRRI 123) to $0.07 \mathrm{~g}$ (MERMENTAU, a released japonica variety) and 0.10 (BOWMAN and CL151-released japonica varieties; and RU1304154 - a japonica breeding line) to $0.32 \mathrm{~g}$ (IR86635-2-3-3-3 - an indica breeding line) with an average of 0.03 and $0.29 \mathrm{~g}$, respectively (Table S2). INIA Tacuari (an indica released genotype) showed minimum values, whereas IR78049-25-2-2-2 (an indica breeding line) showed maximum values for shoot dry weight and total dry weight at $22 / 14{ }^{\circ} \mathrm{C}$ (Figure 2; Table S2). At high temperature, maximum values for the shoot and total dry weights of $1.78 \mathrm{~g} /$ plant and $2.06 \mathrm{~g} /$ plant, respectively, were recorded in genotype 12DSGMET-25, and minimum values $(0.63 \mathrm{~g} /$ plant for shoot dry weight and $0.77 \mathrm{~g} /$ plant for total dry weight) were recorded in IR09L179 (an indica breeding line). Low temperature reduces the plants' dry weight content [39-41]. Genotype genetic characteristics might be 
responsible for the variability in percentage of shoot dry weight obtained in a day. Rice genotypes having higher total dry weight may have higher temperature stress tolerance than other genotypes.

\subsection{Root Growth and Development}

Root phenotype co-optimizes root architecture to acquire water and essential nutrients [42] to improve plant productivity under diverse growing conditions [43-46]. There is no single root feature ideal for different environmental stress [42,44]. Total root length, root surface area, root volume, and root diameters indicate the root's function under any given growing conditions $[42,44,45]$. These are useful characteristics for nutrient uptake efficiency and performance under various stress conditions, including temperature [46]. The roots are the most sensitive part of the plant to temperature [47]. Therefore, we evaluated the root phenotypic responses of the 64 rice genotypes, intending to identify those with synergistic or antagonistic responses to low and high temperatures.

The overall root system under low temperatures was significantly smaller than the roots under high temperatures. All the root growth and developmental parameters decreased (ranged from 2 to $87 \%$ ) across genotypes under low-temperature conditions, except for root:shoot ratio (Tables S3 and S4). FEDEARROZ MOCARE recorded the maximum value for root length at $22 / 14{ }^{\circ} \mathrm{C}(803 \mathrm{~cm} /$ plant $)$ and at $30 / 22{ }^{\circ} \mathrm{C}(3710 \mathrm{~cm} /$ plant $)$. The maximum value was recorded under high temperature in CT18244-9-4-4-2-1-2 (an indica breeding line, $5132 \mathrm{~cm} /$ plant). Root surface area ranged between $21-83 \mathrm{~cm}^{2} /$ plant with an overall average of $48 \mathrm{~cm}^{2} /$ plant at low-temperature conditions, whereas, at high-temperature conditions, it ranged from 159-555 $\mathrm{cm}^{2} /$ plant with an overall average of $344 \mathrm{~cm}^{2} /$ plant (Figure 3C; Table S3). At optimum temperature, the lowest and highest value for root surface area was $114 \mathrm{~cm}^{2} /$ plant (RU1504122, a japonica breeding line) and $476 \mathrm{~cm}^{2} /$ plant (CT18614-4-1-2-3-2, an indica breeding line), respectively. There was not much difference in the average root diameter values, neither among the temperature treatments nor among the genotypes. The root volume values (Figure 3D) decreased similarly to the longest root length at low temperatures. However, there was not much difference among the genotypes growing at optimum and high temperatures. Similar to the root observations in this study, reduction or increase in temperature depressed root growth, such as root tips (Figure 3A) [47,48].

Root developmental traits such as the number of root tips, the number of root forks, the number of root crossings, and root numbers increased at $38 / 30^{\circ} \mathrm{C}$. Still, they decreased at $22 / 14{ }^{\circ} \mathrm{C}$ in comparison with optimum temperature conditions (Table S4). An $81 \%$ decrease in the number of root tips and an almost $90 \%$ decrease in the number of root forks and crossings were observed at low-temperature conditions compared with high-temperature conditions across rice genotypes (Figure 3A; Table S4). The number of roots ranged from $14.3-49$ /plant at $30 / 22{ }^{\circ} \mathrm{C}$ with an overall average of $26.7 /$ plant, which decreased to $4.7-16.7$ / plant at $22 / 14{ }^{\circ} \mathrm{C}$ with an overall average of 26.7 roots/plant (Table S4). There was an increase of $26 \%$ in the number of roots in the plants growing at high-temperature conditions. The highest number of roots was recorded in CT186515-1-5-1-2-1 (an indica breeding line, $57 /$ plant), whereas SABINE was found to have the least number of roots (18/plant). Genotypes with superior root development traits (number of crossings, RT, and RF densities) suggests developing a more branched root system directly related to the water and nutrient uptake potential of the plant [42]. Higher RCs, RTs, and RFs could lead to a better genotypic ability to compete in the uptake of nutrients and water from the soil profile. Therefore, genotypes with more tips, forks, and crossings should better tolerate extreme-temperature environmental conditions by maximizing nutrient and water uptake than rice genotypes with fewer numbers of those traits [43-46]. On average, rice genotypes under high-temperature conditions showed 26 and 56\% lower root:shoot ratios than genotypes under optimum temperature and low-temperature conditions, respectively (Table S4). They were indicating the genetic variability in relative carbon allocation between the shoot and roots under extreme temperature. Compared with other genotypes, 
MERMENTAU and RU1304154 (japonica breeding line) had the highest root-to-shoot ratio under low temperature (Table S4). As may be expected, the 12DS-GMET-25 and Apo (a drought-tolerant genotype [49]) genotypes had the maximum root:shoot ratio under high temperature relative to control (Table S4). The decrease in root:shoot ratio caused by high soil temperature may be attributed to inhibition of the formation and elongation of the primary root [50,51], decreased distribution of carbohydrates to root [52], and increased respiration [53].

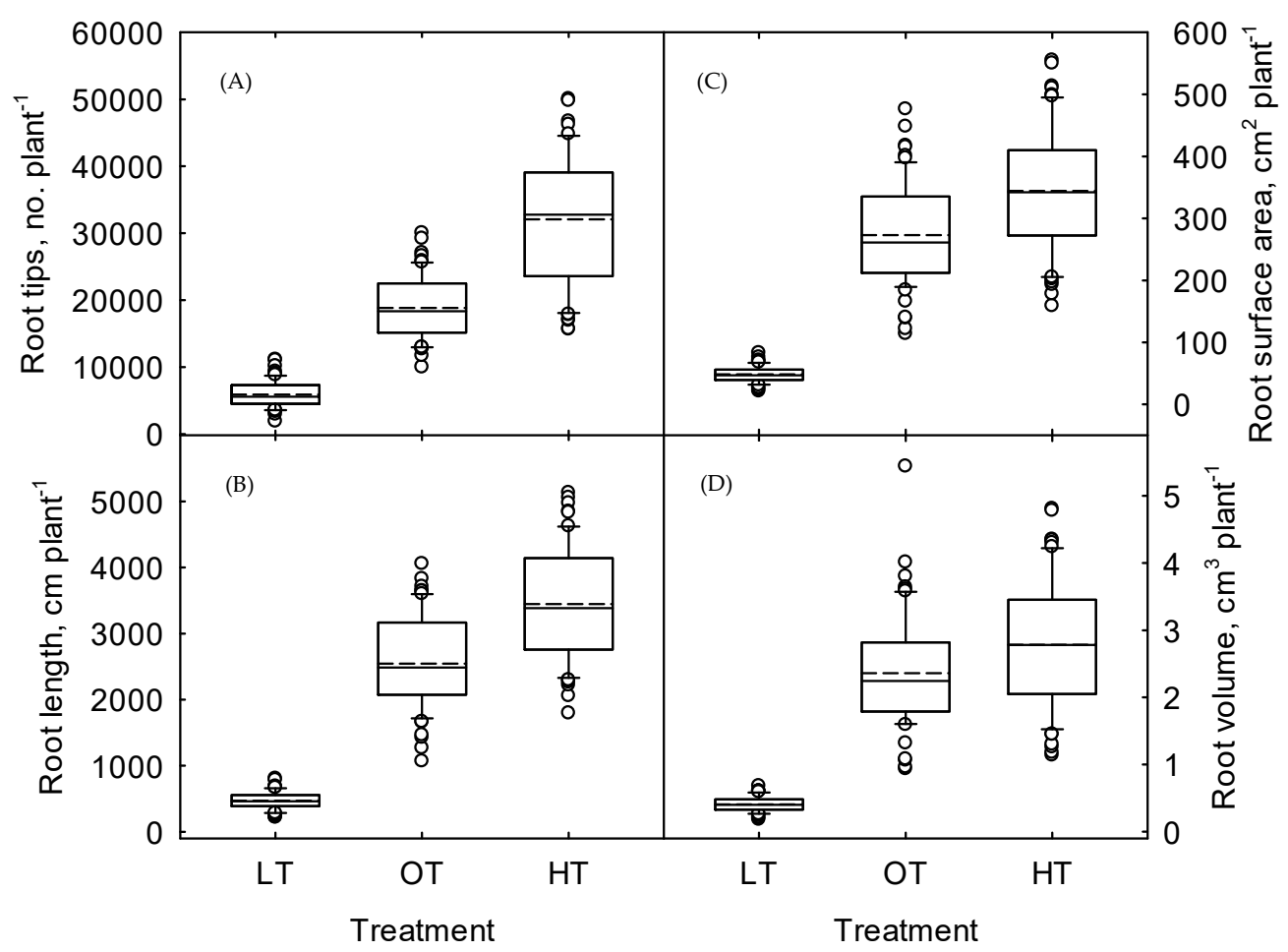

Figure 3. Temperature effects (low temperature-LT, optimum temperature-OT and high temperature-HT) on (A) root tips, (B) root length, (C) root surface area, and (D) root volume of 64 rice genotypes. Measurements were taken at 21 days after sowing. The middle line indicates the median; the box shows the range of the 25 th to 75 th percentiles of the total data. The whiskers indicate the interquartile range, and the outer dots are outliers.

\subsection{Physiological Traits}

The chlorophyll index and maximal quantum yield of photosystem II $\left(\mathrm{F}_{\mathrm{v}} / \mathrm{F}_{\mathrm{m}}\right)$ are essential parameters for the photosystem II activity. Cold stress reduces significantly the concentration of chlorophyll in susceptible rice genotypes [36,54]. Chlorophyll index was used as a tool to evaluate the degree of cold tolerance of transgenic plants [55] and ecotype [36], to monitor plant recovery after stress [56], and to compare chilling tolerance between distinct hybrid genotypes during grain filling [52]. On average, the non-destructive leaf chlorophyll index increased by $8 \%$ with increased temperature from optimum to high levels (Figure 4A). On the contrary, the chlorophyll index decrement was more substantial $(62 \%)$ under low temperatures. SPAD values ranged between 5 and 17 with an overall average of 12 at $22 / 14{ }^{\circ} \mathrm{C}$, whereas it ranged from $25-40$ with an overall average of 32 at $30 / 22^{\circ} \mathrm{C}$ (Figure $4 \mathrm{~A}$; Table S5). At $38 / 30^{\circ} \mathrm{C}$ the maximum chlorophyll index was recorded in IR65600-81-5-2-3 (an indica breeding line, 41), whereas HHZ 1-Y4-Y1 had the lowest value (another indica breeding line, 27). Slight differences in the fluorescence among treatments and genotypes (Figure 4B-D) suggest some level of stress-induced photosystem damage or increase in non-photochemical activities under extreme temperature [57]. The reduced chlorophyll index values under low temperature is due to reactive oxygen species (ROS)- 
induced impaired pigment biosynthetic pathways, degradation of chloroplast membrane, or increased lipid peroxidation [20,36]. However, the chlorophyll index and fluorescence variability in response to extreme temperature suggest new opportunities for selection and genetic improvement in rice [36] and other C4 crops [57].

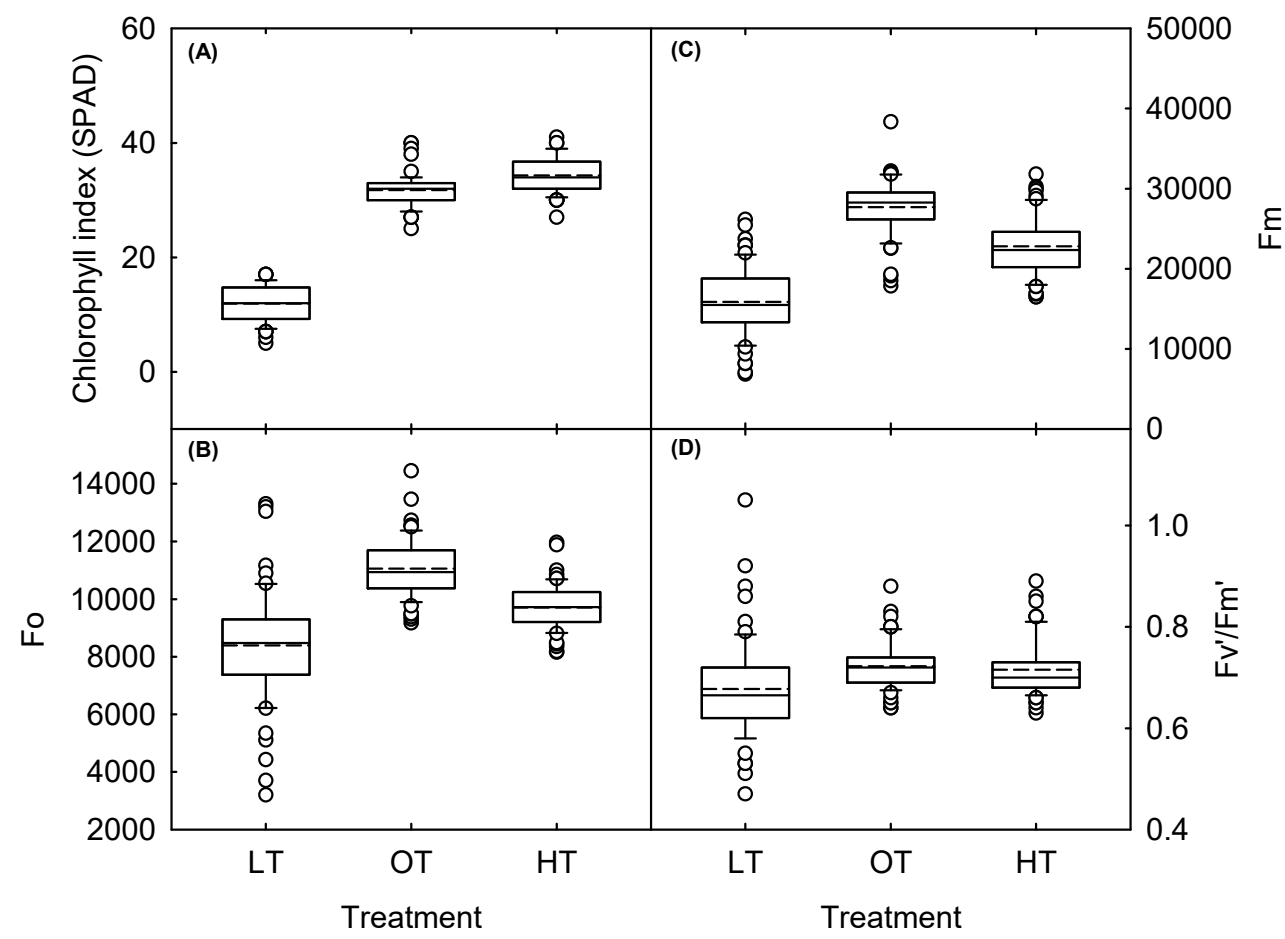

Figure 4. Temperature effects (low temperature-LT, optimum temperature-OT and high temperature-HT) on (A) chlorophyll concentration, $(\mathbf{B})$ minimal fluorescence intensity $\left(F_{\mathrm{O}}\right),(\mathbf{C})$ maximal fluorescence intensity $\left(F_{m}\right)$, and $(D)$ chlorophyll fluorescence $\left(F_{v} / F_{m}\right)$ of 64 rice genotypes. Measurements were taken at 21 days after sowing. The middle line indicates the median, and the box shows the range of the 25 th to 75 th percentiles of the total data. The whiskers indicate the interquartile range, and the outer dots are outliers.

\subsection{Phenotypic Trait Correlations and Contributions of Component Traits to Seedling Vigor}

In the present study, principal components (PC) analysis was performed to identify each trait's contributions that best described temperature response. The PCA was performed using relative responses of physiological, root, and shoot traits. Based on the PCA analysis, the first two PC cumulatively explained $>43.3 \%$ in low temperatures (Figure 5A) and $>43.8 \%$ under high-temperature (Figure $5 \mathrm{~B}$ ) stress of the total phenotypic variation. The root and shoot traits contributed more than the physiological traits to the separation of the rice genotypes (Figure 5). The rice genotypes variation in the first PC was mostly explained by root parameters (forks, RSA, RL, RV, and RC) in low-temperature stress, and LA (Figure 5A) and StWT under high temperatures (Figure 5B). The second PC variation was explained by seedling vigor traits such as shoot weight (SHWT), LWT, and R/S under low-temperature treatment (Figure 5A). Interestingly, physiological ( $\mathrm{F}_{\mathrm{m}}$, $\mathrm{F}_{\mathrm{V}}$, and $\mathrm{F}_{\mathrm{o}}$ ) and seedling vigor (LWT, SHWT, TdWT, and R/S) were found to be associated with PC2 in high-temperature stress (Figure $5 B$ ). Seedling vigor (final seedling biomass) was significantly $(p<0.05)$ correlated with most of its components or related traits in both low and high temperature treatments. However, a significant negative $(p<0.05)$ correlation of shoot weight was observed with root:shoot ratio in low- $(r=-0.37)$ and high- $(r=-0.54)$ temperature treatments (Figure S1). The response of total seedling dry weight (TdWT) to low-temperature treatment was not significantly $(p>0.05)$ correlated with root:shoot ratio. Unlike in the low-temperature treatment, the correlations of chlorophyll fluorescence parameters $\left(\mathrm{F}_{\mathrm{o}}, \mathrm{F}_{\mathrm{m}}\right.$, and $\left.\mathrm{F}_{\mathrm{v}}\right)$ with $\mathrm{R} / \mathrm{S}$ and root tips were negative in response to high tem- 
perature. However, $\mathrm{F}_{\mathrm{v}} / \mathrm{F}_{\mathrm{m}}$ 's correlation with leaf area was positive under low temperature $(r=0.29)$, but the same relationship was nonsignificant under high temperature (Figure S1). Similar methodologies have been applied for the successful screening of corn (Zea mays L.) hybrids for cold tolerance [32], rice genotypes for drought tolerance [58], and soybean (Glycine max [L.] Merr) genotypes for evaluating low- and high-temperature tolerance [41].
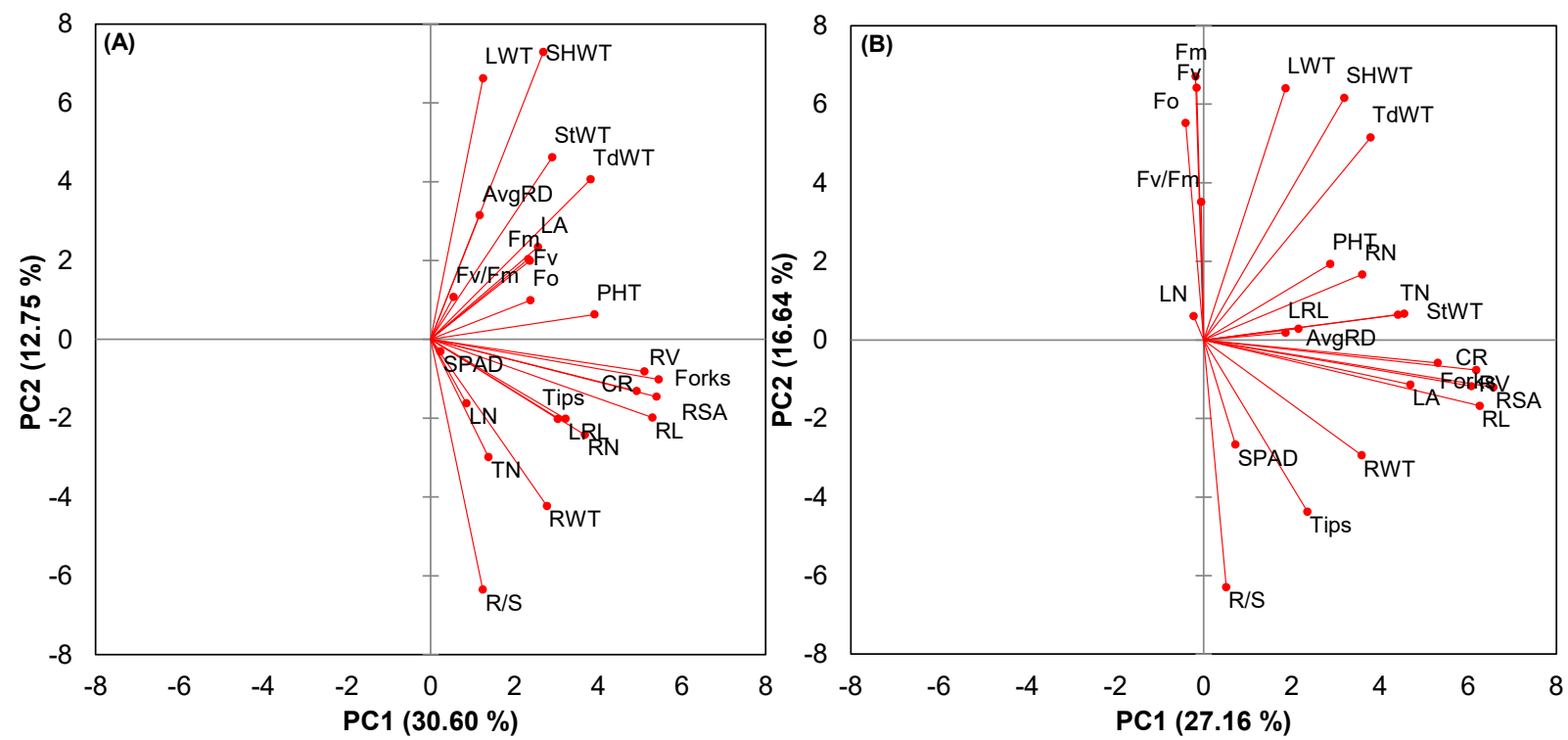

Figure 5. Principle component (PC) analysis for morphological and physiological traits of 64 rice genotypes in response to low temperature (A) and high temperature (B). Plant height (PH), tiller number (TN), number of leaves (LN), leaf area (LA), leaf weight (LWT), stem weight (StWT), shoot weight (SHWT), seedling total dry weight (TdWT), longest root length (LRL), average root diameter (AvgRD), root volume (RV), root tips (RT), root forks (RF), root crossings (RC), root length (RL), root surface area (RSA), root dry weight (RWT), root number (RN), chlorophyll index (SPAD), minimal fluorescence intensity $\left(F_{\mathrm{o}}\right)$, maximal fluorescence intensity $\left(\mathrm{F}_{\mathrm{m}}\right)$, maximal variable fluorescence $\left(\mathrm{F}_{\mathrm{v}}\right)$, and chlorophyll fluorescence $\left(\mathrm{F}_{\mathrm{v}} / \mathrm{F}_{\mathrm{m}}\right)$.

\subsection{Cumulative Low and High-Temperature Response Index}

The cumulative temperature response index (CTRI) technique [24,32,40] was used to identify genotypes with low- and high-temperature (low-CLTRI and high-CHTRI) tolerance in the 64 rice genotypes. The most robust correlation coefficient was recorded between CLTRI and root $\left(r^{2}=0.64\right)$ followed by physiology $\left(r^{2}=0.64\right)$ low-temperature response index, implying that root and physiological parameters are crucial for lowtemperature tolerance (Figure 6A). A weak correlation was observed between CHTRI and physiological traits under high temperature, indicating that root and shoot traits are more useful for selecting vigorous genotypes for heat tolerance at the seedling stage (Figure 6B). High temperature alters cell properties or activities such as enzyme kinetics, protein binding, and membrane fluidity due to excess ROS generation [59]. Heat-stressinduced changes in cell physical properties (degradation of chloroplast membrane or increased lipid peroxidation) partially explain the weaker relationship between CHTRI and physiological traits.

Further, a weak correlation $\left(\mathrm{r}^{2}=0.1\right)$ between CHTRI and CLTRI for shoot, root, and physiological parameters, indicates that heat and cold tolerance mechanisms are distinct. We also tested each trait's relative contribution to CHTRI or CLTRI through multiple linear regression (Table S6). Thirteen traits (PHT, TN, LN, LA, LWT, StWT, RWT, LRL, RT, RF, RC, RN, and SPAD) significantly contributed to CHTRI during seedling development under high-temperature stress treatment. In contrast, only five traits involving root and physiological traits (RWT, RC, RN, SPAD, and $F_{\mathrm{o}}$ ) significantly and positively contributed to CLTRI under low temperature for seedling vigor (Table S6). These findings suggest 
that developing tolerance for low and high temperatures at the seedling stage may require different selection strategies.
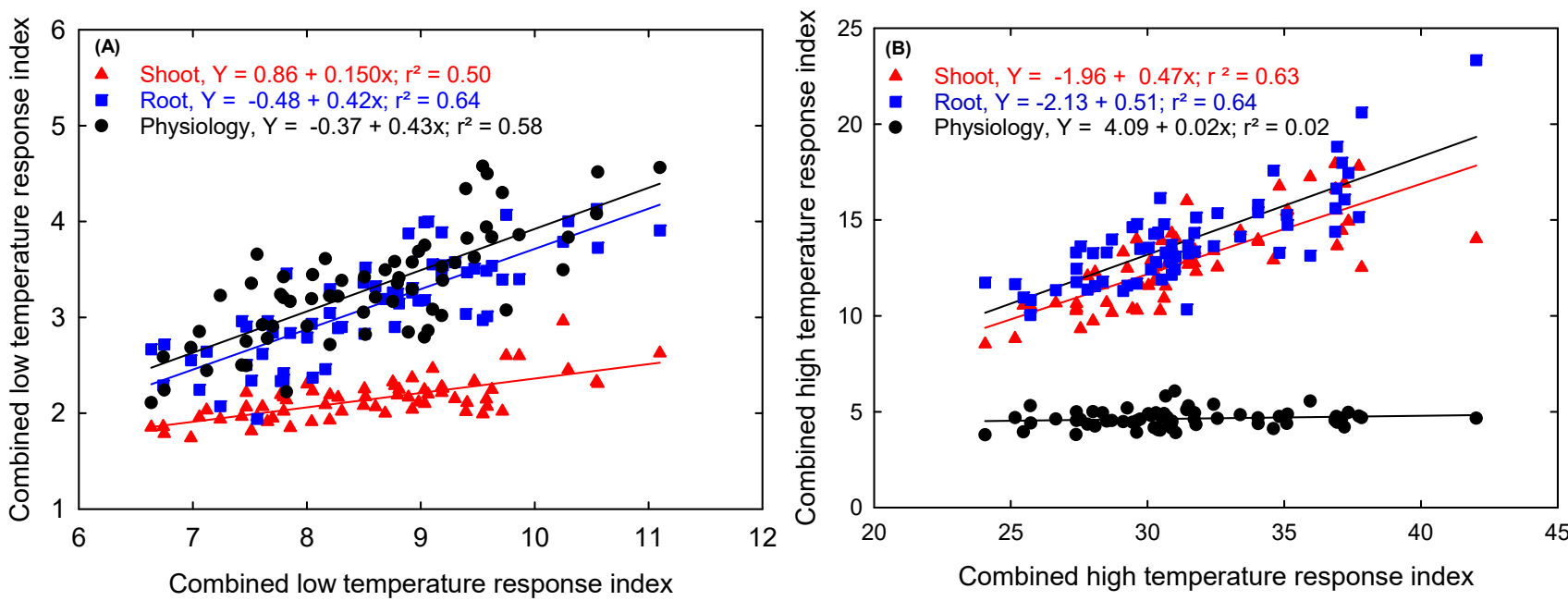

Figure 6. Correlation between combined low-temperature response index (CLTRI, A), combined high-temperature response index (CHTRI, B), and root, shoot, and physiological of 64 rice genotypes.

Based on the CLTRI values, 13 genotypes were classified as low cold-tolerant (coldsensitive), 19 were moderately cold tolerant, 24 were highly cold tolerant, and 8 were very highly cold-tolerant genotypes (Table 1 ). It was observed that among the 19 moderately cold-tolerant genotypes, most of the genotypes were indica types, and among the 8 very highly cold-tolerant genotypes, most of them belonged to the japonica subspecies (Table 1). This indicated that japonica rice genotypes are more tolerant of low temperatures and perform better under such conditions, similar to other studies [12,36,60]. The lowest value of CLTRI was recorded in CT6510-24-1-2 (an indica line, 6.63), whereas RU1504114 (a japonica line) showed the highest value (11.09). Similarly, based on the CHTRI values, 10 genotypes were classified as low heat-tolerant or heat-sensitive, 31 (around $48 \%$ ) were moderately heat-tolerant, 12 highly heat tolerant, and 11 were very highly heat-tolerant genotypes. In the highly heat-tolerant and very highly heat-tolerant category, most of the genotypes were indica rice genotypes, suggesting the potential of higher tolerance of indica compared with japonica genotypes to high temperatures. IR65600-81-5-2-3, an indica breeding line, had the highest CHTRI value (42.02), whereas IR09L179 (another indica line, 24.06) showed the least (Table 2). Based on the CHTRI, eleven genotypes outperformed the well-known reproductive stage tolerant genotype, $\mathrm{N}-22[16,27,61]$. These observations reveal the existence of different high-temperature stress tolerance mechanisms between vegetative and reproductive in rice. Thus, breeding for heat tolerance combined with vegetative and reproductive or grain filling, would help minimize environmental stresses. The identified heat- or cold-tolerant genotypes in this study could be useful to rice breeders in both tropical and temperate rice-growing countries as genetic donors to develop new rice genotypes that could withstand either low- or high-temperature conditions, or both temperature extremes, during the early season under dry direct seeding cultivation practice $[9,14,62]$. Such potential new varieties can also widen the timeframe for growing rice in areas affected by low- and/or high-temperature stress early in the growing season, thus avoiding and/or escaping other biotic and abiotic stress that occur later in the season. 
Table 1. Classification of rice genotypes into various cold-tolerance groups based on combined low-temperature response index (CLTRI).

\begin{tabular}{|c|c|c|c|}
\hline Low Cold Tolerance & Moderately Cold Tolerance & High Cold Tolerance & Very High Cold Tolerance \\
\hline $6.6343-7.6464$ & $7.6465-8.6585$ & $8.6585-9.6706$ & $>9.6707$ \\
\hline CT6510-24-1-2 (6.6343) & MILYANG 240 (7.6545) & CL163 (8.6878) & RU1504197 (9.7162) \\
\hline CT18237-13-11-3-3-5-1 (6.7392) & CT6946-9-1-2-M-1P (7.6995) & $\operatorname{Rex}(8.7552$ & NIPONBARE (9.7499) \\
\hline CT18372-8-1-6-3-1-5 (6.7477) & CT18244-9-4-4-2-1-2 (7.7703) & Sabine (8.7711) & $\mathrm{N}-22(9.8631)$ \\
\hline 12DS-GMET-15 (6.9824) & IR78049-25-2-2-2 (7.7949) & RoyJ (8.7959) & LAKAST (10.2485) \\
\hline FEDEARROZ 473 (7.0562) & CT18245-4-7-1-1-2-1 (7.7961) & El Paso 144 (8.8085) & CL111 (10.2936) \\
\hline IRRI 123 (7.1203) & IR65600-81-5-2-3 (7.8207) & Bowman (8.8909) & RU1404156 (10.5430) \\
\hline CT18615-1-5-1-2-1 (7.2403) & CT19561-3-57-2P-2-1-2-M (7.8536) & RU1504122 (8.9239) & CL271 (10.5537) \\
\hline FEDEARROZ 2000 (7.4287) & HHZ 1-Y4-Y1 (8.0026) & CL151 (8.9251) & RU1504114 (11.0994) \\
\hline RU1504083 (7.4676) & IR86635-2-3-3-3 (8.0417) & RU1402174 (8.9802) & \\
\hline CT18247-12-8-1-4-2-2 (7.4685) & CT18614-4-1-2-3-2 (8.0502) & IR09L179 (9.0320) & \\
\hline COLOMBIA XXI (7.5123) & CT18233-15-6-6-4-8-1 (8.1615) & JES (9.0341) & \\
\hline WAB 56-125 (7.5625) & IR86052-32-3-2 (8.1997) & RU1204156 (9.0628) & \\
\hline \multirow{12}{*}{ RU1504154 (7.6098) } & RU1404196 (8.2025) & Taggart $(9.1040)$ & \\
\hline & 12DS-GMET-25 (8.2734) & RU0603075 (9.1826) & \\
\hline & IR64-EMF NIL (8.3062) & RU1304154 (9.1826) & \\
\hline & FEDEARROZ 21 (8.4975) & CT18593-1-7-2-2-5 (9.1930) & \\
\hline & Thad (8.5053) & MERMENTAU (9.2998) & \\
\hline & Cheniere (8.51322) & IrGA 409 (9.3959) & \\
\hline & Apo (8.6027) & FEDEARROZ MOCARE (9.4066) & \\
\hline & & RU1204197 (9.4702) & \\
\hline & & RU1303138 (9.5439) & \\
\hline & & IR6 (PAKISTAN) (9.5753) & \\
\hline & & INIA Tacuari (9.5826) & \\
\hline & & RU1504198 (9.6234) & \\
\hline
\end{tabular}

Table 2. Classification of rice genotypes into various heat-tolerance groups based on combined high-temperature response index (CHTRI).

\begin{tabular}{|c|c|c|c|}
\hline Low Heat Tolerance & Moderate Heat Tolerance & High Heat Tolerance & Very High Heat Tolerance \\
\hline $24.0647-27.8029$ & $27.8030-31.5410$ & $31.5411-35.2792$ & $35.2793-39.0174$ \\
\hline $\begin{array}{c}\text { IR09L179 }(24.0647) \\
\text { JES }(25.1469) \\
\text { IR8652-32-3-2 (25.4620) } \\
\text { RU1504197 (25.7155) } \\
\text { 12DS-GMET-15 (25.7315) } \\
\text { CT6946-9-1-2-M-1P (26.6467) } \\
\text { FEDEARROZ 2000 (27.3866) } \\
\text { CT18615-1-5-1-2-1 (27.4010) } \\
\text { RU1303138 (27.4013) } \\
\text { Taggart (27.5529) }\end{array}$ & $\begin{array}{c}\text { NIPONBARE (27.8056) } \\
\text { CT19561-3-57-2P-2-1-2-M (28.0089) } \\
\text { CT18233-15-6-6-4-8-1 (28.0844) } \\
\text { Thad (28.3560) } \\
\text { IR86635-2-3-3-3 (28.5095) } \\
\text { CT6510-24-1-2 (28.6993) } \\
\text { FEDEARROZ MOCARE (29.1116) } \\
\text { Sabine (29.2603) } \\
\text { CT18245-4-7-1-1-2-1 (29.4525) } \\
\text { RU1504154 (29.6024) } \\
\text { Apo (29.6167) } \\
\text { RU1402174 (29.7321) } \\
\text { COLOMBIA XXI (30.0382) } \\
\text { CL271 (30.1294) } \\
\text { FEDEARROZ 21 (30.2457) } \\
\text { CL163 (30.3132) } \\
\text { CL151 (30.3852) } \\
\text { RU1204156 (30.4613) } \\
\text { WAB 56-125 (30.5225) } \\
\text { RU1304154 (30.6095) } \\
\text { RoyJ (30.6671) } \\
\text { RU1404156 (30.7194) } \\
\text { RU1504198 (30.8046) } \\
\text { MERMENTAU (30.8833) } \\
\text { RU1404196 (30.8856) } \\
\text { 12DS-GMET-25 (30.8925) } \\
\text { IR64-EMF NIL (30.9995) } \\
\text { FEDEARROZ 473 (31.0337) } \\
\text { CT18614-4-1-2-3-2 (31.4380) } \\
\text { RU1504083 (31.4866) } \\
\text { CT18244-9-4-4-2-1-2 (31.4997) }\end{array}$ & $\begin{array}{c}\text { CT18247-12-8-1-4-2-2 (31.7148) } \\
\text { IrGA 409 (31.7274) } \\
\text { CT18237-13-11-3-3-5-1 (31.7754) } \\
\text { Rex (32.4221 } \\
\text { Cheniere (32.5563) } \\
\text { CL111 (33.3937) } \\
\text { CT18372-8-1-6-3-1-5 (34.0439) } \\
\text { IR6 (PAKISTAN) (34.0496) } \\
\text { RU0603075 (34.6069) } \\
\text { LAKAST (34.8213) } \\
\text { El Paso 144 (35.0925) } \\
\text { N-22 (35.1243) }\end{array}$ & $\begin{array}{c}\text { INIA Tacuari (35.9532) } \\
\text { RU1204197 (36.8627) } \\
\text { CT18593-1-7-2-2-5 (36.8784) } \\
\text { IRRI 123 (36.9060) } \\
\text { Bowman (36.9310) } \\
\text { RU1504122 (37.1084) } \\
\text { IR78049-25-2-2-2 (37.2010) } \\
\text { HHZ 1-Y4-Y1 (37.3457) } \\
\text { RU1504114 (37.7292) } \\
\text { MILYANG 240 (37.8333) } \\
\text { IR65600-81-5-2-3 (42.0246) }\end{array}$ \\
\hline
\end{tabular}




\subsection{Distinct Rice Genotypes Associated with Low-and/or High-Temperature Tolerance}

Genetic-based approaches for mitigating critical environmental stresses, including extreme temperatures, have been emphasized in rice, starting with identifying genetic donors for breeding [27]. Groups of contrasting rice genotypes were selected based on CHTRI and CLTRI, following a normalized $Z$ distribution method (Figure 7A). Four groups of rice genotypes, representing high- and low-temperature-tolerant (HTT+LTT), high-temperature-tolerant and low-temperature-sensitive (HTT+LTS), high-temperaturesensitive and low-temperature-tolerant (HTS+LTT), and high-temperature-sensitive and low-temperature-sensitive (HTS+LTS) groups were identified and classified as combined cold- and heat-stress resilient, only high-temperature tolerant, only tolerant of low temperature, and heat-stress sensitive, respectively (Figure 7A).
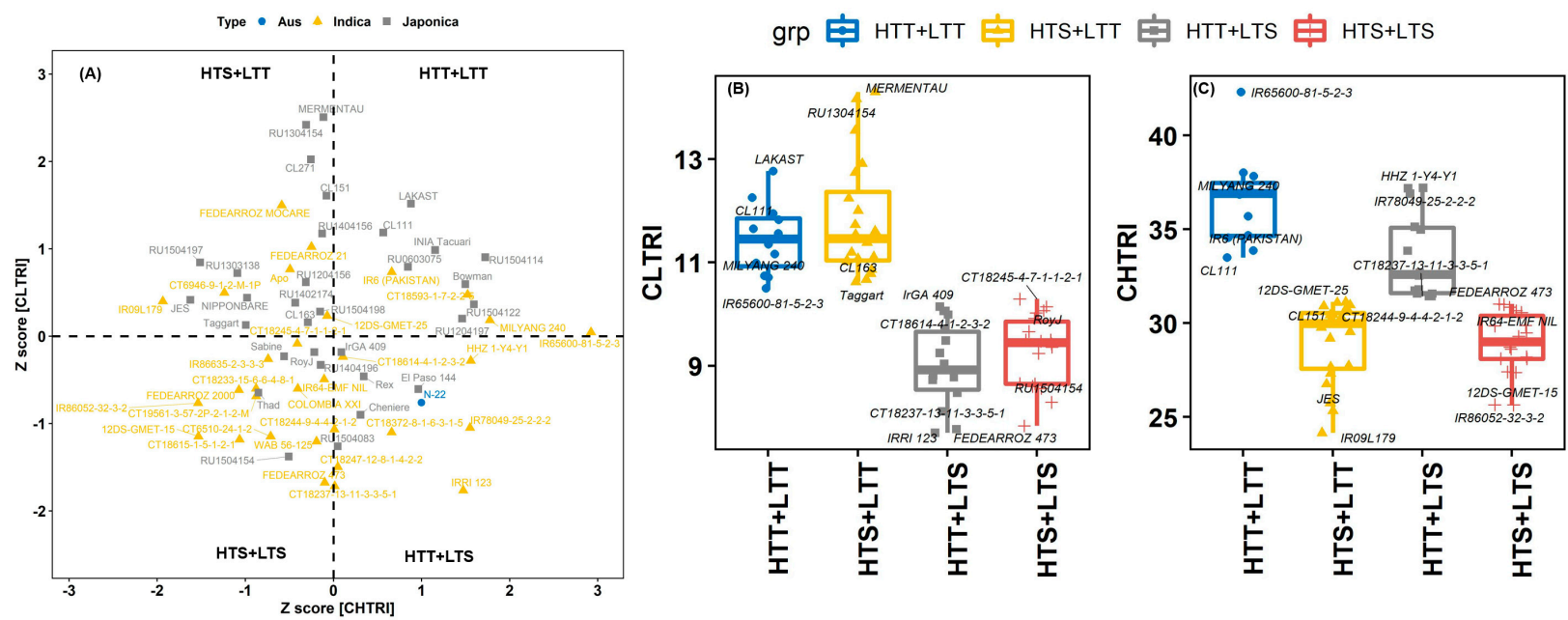

Figure 7. Selection of heat-stress-resilient and -sensitive rice lines based on combined high-temperature response index (CHTRI) and combined low-temperature response index (CLTRI). Normalized Z values were estimated for CHTRI and CLTRI for each line, and the estimated $Z$ score were used to select rice genotypes with a contrasting response under extreme temperature. The figure's quadrant shows rice genotypes with contrasting responses to low and high-temperature stress (A). The genotypes were grouped into four contrasting groups based on their response to low temperature (B) and high temperature $(\mathbf{C})$ during the seedling stage, and their cumulative phenotypic responses were graphed.

Based on the $\mathrm{Z}$ score of CLTRI and CHTRI values, 12 genotypes were classified as lowand high-temperature tolerant (HTT+LTT), 34 were intermediate cold (20, HTS+LTT)or high-temperature tolerant (14, HTT+LTS), 24 were highly cold-tolerant, and 18 were lowand high-temperature-sensitive genotypes (Figure 7A). The selected heat-stress-resilient (HTT+LTT) genotypes had high CHTRI (36.5) and CLTRI (11.5) when exposed to high- and low-temperature stress at the seedling stage, respectively (Figure 7B,C).

Within the heat-stress-resilient group (HTT+LTT), the genotype LAKAST (a released japonica genotype) recorded higher CLTRI (30.4\%) than the heat-sensitive group. Likewise, the genotype IR65600-81-5-2-3 had higher CHTRI by 36.5\% compared with the sensitive group. On the contrary, the genotypes FEDEARROZ 473 and IR86052-32-32 recorded $31.6 \%$ and $30 \%$ lower CLTRI and CHTRI compared with the HTT+LTT group (Figure 7B,C). Based on the CLTSI performance in this study, five japonicas (breeding line RU1304154, and released varieties CL271, CL151, MERMENTAU, and LAKAST) are expected to be more useful for developing varieties for areas with the cold stress that occurs early in the cropping season. On the other hand, three indica genotypes (breeding lines IR65600-81-5-2-3 and HHZ 1-Y4-Y1 and genotype MILYANG 240) and two japonica breeding lines (RU1504114 and RU1504122) performed well under high-temperature stress at the early seedling stage based on CHTSI. Finally, genotypes that performed well under both low- and high-temperature treatments included two indica breeding lines (IR65600-81-5-23 and CT18593-1-7-2-2-5), two japonica breeding lines under development (RU1504114 and 
RU1504122), and two japonica released genotypes (Bowman and INIA Tacuari). Most improved rice varieties grown under current production systems have been developed for optimal growing conditions and were not intentionally bred for unfavorable environmental conditions $[27,63]$. Therefore, the heat- and/or cold-tolerant genotypes identified in this study, which encompassed a broad range of genetic diversity, involving both the two major rice subspecies of indica and japonica, could help breeders develop new rice genotypic combinations that would possess low- and or high-temperature tolerance early in the growing season.

\section{Conclusions}

The 64 rice genotypes examined in this study exhibited substantial variability in their responses for root and shoot traits. By screening a diverse set of rice genotypes, encompassing both the indica and japonica major rice subspecies, we were able to identify genotypes, including released varieties and experimental breeding lines still under development, that are tolerant of extreme temperatures. Cold stress caused significant reductions in all root, shoot, and physiological traits, whereas a significant increase in all traits was observed under high temperatures among genotypes, compared with optimum temperatures. Our results indicated that rice is more sensitive to low temperatures than high temperatures at the seedling stage. The CTRI-based technique provided a means for quantifying total variability, and thus, may be useful as selection criteria for screening rice genotypes for cold or heat tolerance. This information would help determine which (shoot or root) traits are best suited among rice genotypes for improving cold and heat tolerance. Genotypes identified to be cold-tolerant and heat-tolerant may be used as genetic donors for developing new rice varieties or hybrids that can withstand low-temperature, high-temperature, and/or both extreme conditions under both tropical and temperate climate. With improved plasticity, identified new extreme temperature-resilient genotypes could grow rice under a broader range of geophysical and temporal environments. However, these results should be validated under field conditions to evaluate their performance before recommending them to the producers and breeders to accomplish the maximum benefit.

Supplementary Materials: The following are available online at https: / www.mdpi.com/2073-4 395/11/1/112/s1, Table S1: Plant height (PH), tiller number (TN), leaf number (LN) and leaf area (LA), measured in low-temperature (LT), optimum-temperature (OT) and high-temperature (HT) stress conditions in 64 rice genotypes, Table S2: Dry weight traits measured in low-temperature (LT), optimum-temperature (OT) and high-temperature (HT) stress conditions in 64 rice genotypes, Table S3: Root growth traits: root length (RL), root surface area (RSA), root average diameter (AvgRD), root volume (RV) and longest root length (LRL), measured in low-temperature (LT), optimumtemperature (OT) and high-temperature (HT) stress conditions in 64 rice genotypes, Table S4: Root tips (RT), root forks (RF), root crossings (RC), root number (RN), and root:shoot ratio measured in lowtemperature (LT), optimum-temperature (OT) and hightemperature (HT) stress conditions in 64 rice genotypes, Table S5: Chlorophyll index and chlorophyll fluorescence measured in low-temperature (LT), optimum-temperature (OT) and high-temperature (HT) stress conditions in 64 rice genotypes, Table S6: Multiple linear regression of combined high-temperature response index (CHTRI) and combined low-temperature response index (CLTRI) with the induvial responses index of twenty-four traits in response to low and high temperature. Figure S1: Correlation matrix among traits in response to low- and high-temperature stress in rice.

Author Contributions: K.R.R.: conceptualization, project administration, methodology, supervision, funding acquisition, review, co-writing, editing \& review, and data analysis \& curation, R.B.: formal analysis, review, co-writing-original draft, editing, and data visualization. A.S.: co-writing the original draft, review, E.D.R.: editing, review, and funding, S.J.: data collection, analysis, and review, F.A.A., A.A.L., C.W., N.K. and S.T.: data collection and review, D.C. and W.G.: review. All authors have read and agreed to the published version of the manuscript.

Funding: We thank the Mississippi Rice Promotion Board and the National Institute of Food and Agriculture, NIFA 2019-34263-30552, and MIS 043050 for partial funding to carry out this research. 
Institutional Review Board Statement: Not applicable for study.

Informed Consent Statement: Not applicable for study.

Data Availability Statement: Data sharing not applicable.

Acknowledgments: We thank David Brand for technical assistance and graduate students at the Environmental Plant Physiology Laboratory for help during data collection.

Conflicts of Interest: The authors declare no conflict of interest.

$\begin{array}{ll}\text { Abbreviations } \\ & \\ \text { CHTRI } & \text { Cumulative high-temperature response index } \\ \text { CLTRI } & \text { Cumulative low-temperature response index } \\ \text { CTRI } & \text { Cumulative temperature response index } \\ \text { DAS } & \text { Days after sowing } \\ \mathrm{F}_{\mathrm{m}} & \text { maximal fluorescence intensity } \\ \mathrm{F}_{\mathrm{O}} & \text { minimal Fluorescence Intensity } \\ \mathrm{F}_{\mathrm{V}} & \text { maximal variable fluorescence } \\ \mathrm{F}_{\mathrm{V}} / \mathrm{F}_{\mathrm{m}} & \text { Chlorophyll fluorescence } \\ \text { HTS } & \text { High-temperature sensitive } \\ \text { HTT } & \text { High-temperature tolerant } \\ \text { IHSRI } & \text { Individual heat-stress response index } \\ \text { ILSRI } & \text { Individual low-stress response index } \\ \text { LA } & \text { Leaf area } \\ \text { LN } & \text { Total number of leaves } \\ \text { LTS } & \text { Low-temperature sensitive } \\ \text { LTT } & \text { Low-temperature tolerant } \\ \text { LWT } & \text { Leaf dry weight } \\ \text { PCA } & \text { Principal Component Analysis } \\ \text { PH } & \text { Plant height } \\ \text { AvgRD } & \text { Root average diameter } \\ \text { RC } & \text { Root crossings } \\ \text { RF } & \text { Root forks } \\ \text { RI } & \text { Relative injury } \\ \text { RL } & \text { Root length } \\ \text { RN } & \text { Root number } \\ \text { R/S } & \text { Root:shoot ratio } \\ \text { RSA } & \text { Root surface area } \\ \text { RT } & \text { Root tips } \\ \text { RV } & \text { Root volume } \\ \text { RWT } & \text { Root dry weight } \\ \text { SPAD } & \text { Chlorophyll index } \\ \text { SPAR } & \text { Soil -plant-atmosphere research } \\ \text { StWT } & \text { Stem dry weight } \\ \text { SHWT } & \text { Above-ground dry weight } \\ \text { TdWT } & \text { Total dry weight } \\ \text { TN } & \text { Tiller number } \\ & \end{array}$

\section{References}

1. Manzanilla, D.O.; Paris, T.R.; Vergara, G.V.; Ismail, A.M.; Pandey, S.; Labios, R.V.; Tatlonghari, G.T.; Acda, R.D.; Chi, T.T.N.; Duoangsila, K.; et al. Submergence risks and farmers' preferences: Implications for breeding Sub1 rice in southeast Asia. Agric. Syst. 2011, 104, 335-347. [CrossRef]

2. Lone, J.; Khan, M.N.; Bhat, M.A.; Shikari, A.B.; Wani, S.H.; Sofi, R.N.; Imran Khan, M.; Lone, R.A. Cold tolerance at the germination stage of rice: Methods of evaluation and characterization of genotypes. Int. J. Curr. Microbiol. Appl. Sci. 2018, 7, 1103-1109. [CrossRef]

3. Ali, J.; Xu, J.-L.; Gao, Y.-M.; Ma, X.-F.; Meng, L.-J.; Wang, Y.; Pang, Y.-L.; Guan, Y.-S.; Xu, M.-R.; Revilleza, J.E.; et al. Harnessing the hidden genetic diversity for improving multiple abiotic stress tolerance in rice (Oryza sativa L.). PLoS ONE 2017, 12, e0172515. [CrossRef] [PubMed] 
4. Zhao, K.; Tung, C.-W.; Eizenga, G.C.; Wright, M.H.; Ali, M.L.; Price, A.H.; Norton, G.J.; Islam, M.R.; Reynolds, A.; Mezey, J.; et al. Genome-wide association mapping reveals a rich genetic architecture of complex traits in Oryza Sativa. Nat. Commun. $2011,2,467$. [CrossRef]

5. Singhal, P.; Jan, A.T.; Azam, M.; Haq, Q.M.R. Plant abiotic stress: A prospective strategy of exploiting promoters as alternative to overcome the escalating burden. Front. Life Sci. 2016, 9, 52-63. [CrossRef]

6. Wassmann, R.; Jagadish, S.V.K.; Sumfleth, K.; Pathak, H.; Howell, G.; Ismail, A.; Serraj, R.; Redona, E.; Singh, R.K.; Heuer, S. Regional Vulnerability of Climate Change Impacts on Asian Rice Production and Scope for Adaptation. Adv. Agron. 2009, 102, 91-133.

7. Wani, S.H.; Sah, S.K.; Hossain, M.A.; Kumar, V.; Balachandran, S.M. Transgenic Approaches for Abiotic Stress Tolerance in Crop Plants. In Advances in Plant Breeding Strategies: Agronomic, Abiotic and Biotic Stress Traits; Al-Khayri, J.M., Jain, S.M., Johnson, D.V., Eds.; Springer International Publishing: Cham, Switzerland, 2016; pp. 345-396. ISBN 978-3-319-22517-3.

8. Sandhu, N.; Subedi, S.R.; Singh, V.K.; Sinha, P.; Kumar, S.; Singh, S.P.; Ghimire, S.K.; Pandey, M.; Yadaw, R.B.; Varshney, R.K.; et al. Deciphering the genetic basis of root morphology, nutrient uptake, yield, and yield-related traits in rice under dry direct-seeded cultivation systems. Sci. Rep. 2019, 9, 9334. [CrossRef]

9. Sandhu, N.; Torres, R.O.; Sta Cruz, M.T.; Maturan, P.C.; Jain, R.; Kumar, A.; Henry, A. Traits and QTLs for development of dry direct-seeded rainfed rice varieties. J. Exp. Bot. 2015, 66, 225-244. [CrossRef]

10. Zhang, Q.; Chen, Q.; Wang, S.; Hong, Y.; Wang, Z. Rice and cold stress: Methods for its evaluation and summary of cold tolerance-related quantitative trait loci. Rice 2014, 7, 24. [CrossRef]

11. Najeeb, S.; Ali, J.; Mahender, A.; Pang, Y.L.; Zilhas, J.; Murugaiyan, V.; Vemireddy, L.R.; Li, Z. Identification of main-effect quantitative trait loci (QTLs) for low-temperature stress tolerance germination- and early seedling vigor-related traits in rice (Oryza sativa L.). Mol. Breed. 2020, 40, 10. [CrossRef]

12. Cong Dien, D.; Yamakawa, T. Phenotypic variation and selection for cold-tolerant rice (Oryza sativa L.) at germination and seedling stages. Agriculture 2019, 9, 162. [CrossRef]

13. Yu, B.; Zhu, T.; Breisinger, C.; Hai, N.M. Impacts of Climate Change on Agriculture and Policy Options for Adaptation: The Case of Vietnam; IFPRI Discussion Papers; International Food Policy Research Institute (IFPRI): Washington, DC, USA, 2010.

14. van Oort, P.A.J. Mapping abiotic stresses for rice in Africa: Drought, cold, iron toxicity, salinity and sodicity. Field Crops Res. 2018, 219, 55-75. [CrossRef]

15. Jiang, L.; Xun, M.; Wang, J.; Wan, J. QTL analysis of cold tolerance at seedling stage in rice (Oryza sativa L.) using recombination inbred lines. J. Cereal Sci. 2008, 48, 173-179. [CrossRef]

16. Kilasi, N.L.; Singh, J.; Vallejos, C.E.; Ye, C.; Jagadish, S.V.K.; Kusolwa, P.; Rathinasabapathi, B. Heat stress tolerance in rice (oryza sativa L.): Identification of quantitative trait loci and candidate genes for seedling growth under heat stress. Front. Plant. Sci. 2018, 9, 1578. [CrossRef] [PubMed]

17. Ali, M.G.; Naylor, R.E.L.; Matthews, S. Distinguishing the effects of genotype and seed physiological age on low temperature tolerance of rice (Oryza sativa L.). Exp. Agric. 2006, 42, 337-349. [CrossRef]

18. Shimono, H.; Hasegawa, T.; Iwama, K. Response of growth and grain yield in paddy rice to cool water at different growth stages. Field Crops Res. 2002, 73, 67-79. [CrossRef]

19. Baruah, A.R.; Ishigo-Oka, N.; Adachi, M.; Oguma, Y.; Tokizono, Y.; Onishi, K.; Sano, Y. Cold tolerance at the early growth stage in wild and cultivated rice. Euphytica 2009, 165, 459-470. [CrossRef]

20. da Cruz, R.P.; Sperotto, R.A.; Cargnelutti, D.; Adamski, J.M.; FreitasTerra, T.; Fett, J.P. Avoiding damage and achieving cold tolerance in rice plants. Food Energy Secur. 2013, 2, 96-119. [CrossRef]

21. Aghamolki, M.T.K.; Yusop, M.K.; Oad, F.C.; Zakikhani, H.; Jaafar, H.; Kharidah, S.; Musa, M. Heat Stress Effects on Yield Parameters of Selected Rice Cultivars at Reproductive Growth Stages. Available online: https: / www.semanticscholar.org/paper/ Heat-stress-effects-on-yield-parameters-of-selected-Aghamolki-Yusop/257f66ff020bf2f3bd32a5d94247a0239473ec74 (accessed on 16 December 2020).

22. Krishnan, P.; Ramakrishnan, B.; Reddy, K.R.; Reddy, V.R. High-temperature Effects on Rice Growth, Yield, and Grain Quality. Adv. Agron. 2011, 111, 87-206.

23. Fahad, S.; Bajwa, A.A.; Nazir, U.; Anjum, S.A.; Farooq, A.; Zohaib, A.; Sadia, S.; Nasim, W.; Adkins, S.; Saud, S.; et al. Crop production under drought and heat stress: Plant responses and management options. Front. Plant. Sci. 2017, 8, 1147. [CrossRef] [PubMed]

24. Gajanayake, B.; Reddy, K.R.; Shankle, M.W.; Arancibia, R.A.; Villordon, A.O. Quantifying storage root initiation, growth, and developmental responses of sweetpotato to early season temperature. Agron. J. 2014, 106, 1795-1804. [CrossRef]

25. Raju, B.R.; Mohankumar, M.V.; Sumanth, K.K.; Rajanna, M.P.; Udayakumar, M.; Prasad, T.G.; Sheshshayee, M.S. Discovery of QTLs for water mining and water use efficiency traits in rice under water-limited condition through association mapping. Mol. Breed. 2016, 36, 35. [CrossRef]

26. Raju, B.R.; Narayanaswamy, B.R.; Mohankumar, M.V.; Sumanth, K.K.; Rajanna, M.P.; Mohanraju, B.; Udayakumar, M.; Sheshshayee, M.S. Root traits and cellular level tolerance hold the key in maintaining higher spikelet fertility of rice under water limited conditions. Funct. Plant. Biol. 2014, 41, 930. [CrossRef] [PubMed] 
27. Jagadish, S.V.K.; Septiningsih, E.M.; Kohli, A.; Thomson, M.J.; Ye, C.; Redoña, E.; Kumar, A.; Gregorio, G.B.; Wassmann, R.; Ismail, A.M.; et al. Genetic advances in adapting rice to a rapidly changing climate. J. Agron. Crop. Sci. 2012, 198, 360-373. [CrossRef]

28. Reddy, K.R.; Hodges, H.; Read, J.; Mckinion, J.; Baker, J.T.; Tarpley, L.; Tarpley, L.; Reddy, V.R. Soil-Plant-Atmosphere-Research (Spar) Facility: A Tool for Plant Research and Modeling. Available online: http:// citeseerx.ist.psu.edu/viewdoc/download?doi= 10.1.1.617.9409\&rep=rep1\&type=pdf (accessed on 16 December 2020).

29. Zhao, D.; Reddy, K.R.; Kakani, V.G.; Read, J.J.; Sullivan, J.H. Growth and physiological responses of cotton (Gossypium hirsutum L.) to elevated carbon dioxide and ultraviolet-B radiation under controlled-environmental conditions. Plant. Cell Environ. 2003, 26, 771-782. [CrossRef]

30. Hewitt, E.J. Sand and Water Culture Methods Used in the Study of Plant Nutrition; Technical Communication No. 22, Commonwealth Bureau of Horticulture and Plantation Crops; Commonwealth Agricultural Bureaux: Farnham Royal, UK, 1952.

31. Arai-Sanoh, Y.; Ishimaru, T.; Ohsumi, A.; Kondo, M. Effects of soil temperature on growth and root function in rice. Plant. Prod. Sci. 2010, 13, 235-242. [CrossRef]

32. Wijewardana, C.; Hock, M.; Henry, B.; Reddy, K.R. Screening corn hybrids for cold tolerance using morphological traits for early-season seeding. Crop. Sci. 2015, 55, 851-867. [CrossRef]

33. Boonjung, H.; Fukai, S. Effects of soil water deficit at different growth stages on rice growth and yield under upland conditions. 1. Growth during drought. Field Crops Res. 1996, 48, 37-45. [CrossRef]

34. Makino, A.; Sato, T.; Nakano, H.; Mae, T. Leaf photosynthesis, plant growth and nitrogen allocation in rice under different irradiances. Planta 1997, 203, 390-398. [CrossRef]

35. Ben-Haj-Salah, H.; Tardieu, F. Temperature affects expansion rate of maize leaves without change in spatial distribution of cell length (analysis of the coordination between cell division and cell expansion). Plant. Physiol. 1995, 109, 861-870. [CrossRef]

36. de Freitas, G.M.; Thomas, J.; Liyanage, R.; Lay, J.O.; Basu, S.; Ramegowda, V.; do Amaral, M.N.; Benitez, L.C.; Braga, E.J.B.; Pereira, A. Cold tolerance response mechanisms revealed through comparative analysis of gene and protein expression in multiple rice genotypes. PLoS ONE 2019, 14, e0218019. [CrossRef]

37. Tang, L.; Zhu, X.-C.; Cao, M.-Y.; Cao, W.-X.; Zhu, Y. Relationships of rice canopy par interception and light use efficiency to grain yield. Ying Yong Sheng Tai Xue Bao J. Appl. Ecol. 2012, 23, 1269-1276.

38. Raja Reddy, K.; Hodges, H.F.; McKinion, J.M. Crop Modeling and Applications: A Cotton Example. Adv. Agron. 1997, 59, 225-290.

39. Hnilickova, H.; Dufek, J.; Hnilicka, F.; Ceska, Z.U. Effects of low temperatures on photosynthesis and growth in selected tomato varieties (Lycopersicon esculentum). Sci. Agric. Bohem. Czech. Repub. 2002, 33, 101-105.

40. Singh, B.; Norvell, E.; Wijewardana, C.; Wallace, T.; Chastain, D.; Reddy, K.R. Assessing morphological characteristics of elite cotton lines from different breeding programmes for low temperature and drought tolerance. J. Agron. Crop. Sci. 2018, 204, 467-476. [CrossRef]

41. Alsajri, F.A.; Singh, B.; Wijewardana, C.; Irby, J.T.; Gao, W.; Reddy, K.R. Evaluating soybean cultivars for low- and hightemperature tolerance during the seedling growth stage. Agronomy 2019, 9, 13. [CrossRef]

42. Klein, S.P.; Schneider, H.M.; Perkins, A.C.; Brown, K.M.; Lynch, J.P. Multiple integrated root phenotypes are associated with improved drought tolerance. Plant. Physiol. 2020, 183, 1011-1025. [CrossRef]

43. Paez-Garcia, A.; Motes, C.; Scheible, W.-R.; Chen, R.; Blancaflor, E.; Monteros, M. Root traits and phenotyping strategies for plant improvement. Plants 2015, 4, 334-355. [CrossRef]

44. Bheemanahalli, R.; Hechanova, S.; Kshirod, J.K.; Krishna Jagadish, S.V. Root anatomical traits of wild-rices reveal links between flooded rice and dryland sorghum. Plant. Physiol. Rep. 2019, 24, 155-167. [CrossRef]

45. Costa, C.; Dwyer, L.M.; Zhou, X.; Dutilleul, P.; Hamel, C.; Reid, L.M.; Smith, D.L. Root morphology of contrasting maize genotypes. Agron. J. 2002, 94, 96. [CrossRef]

46. Hammer, G.L.; Dong, Z.; McLean, G.; Doherty, A.; Messina, C.; Schussler, J.; Zinselmeier, C.; Paszkiewicz, S.; Cooper, M. Can changes in canopy and/or root system architecture explain historical maize yield trends in the US Cornbelt? Crop. Sci. 2009, 49, 299-312. [CrossRef]

47. Munyon, J.W.; Bheemanahalli, R.; Walne, C.H.; Reddy, K.R. Developing functional relationships between temperature and cover crop species vegetative growth and development. Agron. J. 2020. [CrossRef]

48. Setter, T.L.; Greenway, H. Growth reductions of rice at low root temperature: Decreases in nutrient uptake and development of chlorosis. J. Exp. Bot. 1988, 39, 811-829. [CrossRef]

49. Venuprasad, R.; Bool, M.E.; Quiatchon, L.; Sta Cruz, M.T.; Amante, M.; Atlin, G.N. A Large-effect QTL for rice grain yield under upland drought stress on chromosome 1. Mol. Breed. 2012, 30, 535-547. [CrossRef]

50. Nagasuga, K.; Murai-Hatano, M.; Kuwagata, T. Effects of low root temperature on dry matter production and root water uptake in rice plant. Plant. Prod. Sci. 2011, 14, 22-29. [CrossRef]

51. Sattelmacher, B.; Marschner, H.; Kühne, R. Effects of root zone temperature on root activity of two potato (Solanum tuberosum L.) clones with different adaptation to high temperature. J. Agron. Crop. Sci. 1990, 165, 131-137. [CrossRef]

52. Xu, Q.; Huang, B. Effects of differential air and soil temperature on carbohydrate metabolism in creeping bentgrass. Crop. Sci. 2000, 40, 1368-1374. [CrossRef]

53. Du, Y.C.; Tachibana, S. Effect of supraoptimal root temperature on the growth, root respiration and sugar content of cucumber plants. Sci. Hortic. 1994, 58, 289-301. [CrossRef] 
54. Aghaee, A.; Moradi, F.; Zare-Maivan, H.; Zarinkamar, F.; Irandoost, H.P.; Sharifi, P. Physiological responses of two rice (Oryza sativa L.) genotypes to chilling stress at seedling stage. Afr. J. Biotechnol. 2011, 10, 7617-7621. [CrossRef]

55. Tian, Y.; Zhang, H.; Pan, X.; Chen, X.; Zhang, Z.; Lu, X.; Huang, R. Overexpression of ethylene response factor TERF2 confers cold tolerance in rice seedlings. Transgenic Res. 2011, 20, 857-866. [CrossRef]

56. Kuk, Y.I.; Shin, J.S.; Burgos, N.R.; Hwang, T.E.; Han, O.; Cho, B.H.; Jung, S.; Guh, J.O. Antioxidative enzymes offer protection from chilling damage in rice plants. Crop. Sci. 2003, 43, 2109-2117. [CrossRef]

57. Ortiz, D.; Hu, J.; Salas Fernandez, M.G. Genetic architecture of photosynthesis in Sorghum bicolor under non-stress and cold stress conditions. J. Exp. Bot. 2017, 68, 4545-4557. [CrossRef] [PubMed]

58. Singh, B.; Reddy, K.R.; Redoña, E.D.; Walker, T. Screening of rice cultivars for morpho-physiological responses to early-season soil moisture stress. Rice Sci. 2017, 24, 322-335. [CrossRef]

59. Lamers, J.; van der Meer, T.; Testerink, C. How plants sense and respond to stressful environments. Plant. Physiol. 2020, 182, 1624-1635. [CrossRef]

60. Xiao, N.; Gao, Y.; Qian, H.; Gao, Q.; Wu, Y.; Zhang, D.; Zhang, X.; Yu, L.; Li, Y.; Pan, C.; et al. Identification of genes related to cold tolerance and a functional allele that confers cold tolerance. Plant. Physiol. 2018, 177, 1108-1123. [CrossRef]

61. Rang, Z.W.; Jagadish, S.V.K.; Zhou, Q.M.; Craufurd, P.Q.; Heuer, S. Effect of high temperature and water stress on pollen germination and spikelet fertility in rice. Environ. Exp. Bot. 2011, 70, 58-65. [CrossRef]

62. Zhang, S.; Zheng, J.; Liu, B.; Peng, S.; Leung, H.; Zhao, J.; Wang, X.; Yang, T.; Huang, Z. Identification of QTLs for cold tolerance at seedling stage in rice (Oryza sativa L.) using two distinct methods of cold treatment. Euphytica 2014, 195, 95-104. [CrossRef]

63. Kumar, A.; Dixit, S.; Ram, T.; Yadaw, R.B.; Mishra, K.K.; Mandal, N.P. Breeding high-yielding drought-tolerant rice: Genetic variations and conventional and molecular approaches. J. Exp. Bot. 2014, 65, 6265-6278. [CrossRef] [PubMed] 